\title{
In situ Rb-Sr dating of muscovite by LA-ICP-MS/MS
}

\author{
SHIQIANG HUANG AND ZHAOSHAN CHANG \\ Colorado School of Mines
}

Presenting Author: shiqianghuang@mymail.mines.edu

The ages of alteration and mineralization is important for both economic geology research and mineral deposit exploration. Kbearing minerals such as biotite, muscovite, illite, K-feldspar, alunite, and some amphibole are common alteration minerals in a wide range of deposit types such as porphyry, epithermal, orogenic, VHMS, skarn, greisen, and pegmatite deposits. Such minerals are currently dated using Ar-Ar dating methods, which is typically time-consuming with a 6-18 months turnaround time and requires mineral separation. With the development of the new generation triple quadrupole MS (Mass Spectrometer), also called QQQ-MS or MS/MS, it is now possible to conduct $\mathrm{Rb}-\mathrm{Sr}$ dating on such instruments. Coupled with laser ablation (LA), it is also possible to do micro-sampling. The advantages of the LAICP-MS/MS Rb-Sr dating technique include shorter analytical time and lower cost.

In this study, the accuracy and precision of in-situ Rb-Sr dating were tested on hydrothermal muscovite from the Wolfram Camp W-Mo pegmatite-greisen deposit, northeast Queensland, Australia, using a RESOlution SE $193 \mathrm{~nm}$ ArF excimer laser ablation system connected to an Agilent 8900 ICP-MS/MS at Colorado School of Mines, USA. The separation of ${ }^{87} \mathrm{Sr}$ from ${ }^{87} \mathrm{Rb}$ was achieved using $\mathrm{O}_{2}$ gas in the reaction cell. The isotopic ratios were calibrated by pressed nano-powder pellet Mica-mg. Data were reduced using an in-house Excel spreadsheet, with the uncertainties in all steps incorporated into the final age uncertainty. The 55 data points of muscovite yield a $\mathrm{Rb}-\mathrm{Sr}$ isochron age of $304 \pm 6 \mathrm{Ma}(2 \sigma ; \mathrm{MSWD}=1.3)$, which is statistically indistinguishable from Ar-Ar muscovite ages (305 \pm $3 ; 308 \pm 3 \mathrm{Ma} ; 2 \sigma)$ and Re-Os molybdenite ages (306 $\pm 3 ; 306 \pm$ $2 \mathrm{Ma} ; 2 \sigma)[1]$. The accuracy and precision $(2 \%)$ of the age show that the in situ $\mathrm{Rb}-\mathrm{Sr}$ technique can be a useful complement to the established Ar-Ar method.

[1] Cheng, Y., Spandler, C., Chang, Z., and Clarke, G., 2018, Volcanic-plutonic connections and metal fertility of highly evolved magma systems: a case study from the Herberton Sn-WMo Mineral Field, Queensland, Australia: Earth and Planetary Science Letters, v. 486, p. 84-93. 